\title{
Dik Temel Yazı Çalışmalarının Özel Öğrenme Güçlüğü Olan Öğrencinin Yazım Hatalarını Düzeltmesine Etkisi
}

\author{
DOI: 10.26466/opus.549544 \\ * \\ $\underline{\text { Yahya Çıkılı }}^{*}$ - Serdal Deniz ${ }^{* *}$ - Hüseyin Barış Kaya ${ }^{* * *}$
}

* Dr. Öğr. Üyesi, Necmettin Erbakan Üni., Ahmet Keleşoğlu Eğitim Fak., Meram/Konya/Türkiye

E-Posta: ycikili@hotmail.com

ORCID: 0000-0002-1144-9095

** Öğr. Gör. Dr., Necmettin Erbakan Üni., Ahmet Keleşoğlu Eğitim Fak., Meram/Konya/Türkiye

E-Posta: serdaldeniz1@gmail.com ORCID: 0000-0001-6606-9308

*** Öğretmen, Milli Eğitim Müdürlüğü, Belen/Hatay/Türkiye

E-Posta: huseyinbariskaya@hotmail.com ORCID: 0000-0002-7515-4827

\begin{abstract}
$\ddot{O} z$
Özel Öğrenme Güçlüğ̈̈ olan bireyler yapılan eğitsel değerlendirme süreci sonunda özelliklerine uygun eğitim ortamlarına yerleştirilmektedir. Bu bireyler genellikle kaynaştırma eğitimi ortamlarına yerleştirilmekte ve yerleştirildikleri eğitim ortamlarında uygulanmakta olan programlara tabi olmaktadırlar. Bu programlarda ise matematik, okuma-yazma gibi akademik beceriler öne çıkmaktadır. Okuma-yazma gibi akademik becerilerin edinimi için öğrenci özelliklerine uygun şekilde gerekli öğretimsel düzenlemelerin yapılması ve gerekli destek hizmetlerinin sunumu gerekmektedir. Çünkü Öğrenme Güçlüğü olan bireylerin en çok sorun yaşadı̆̆̆ becerilerden birisini de yazma ile ilgili beceriler oluşturmaktadır. Bu araştırmanın amacl, özel öğrenme güçlü̆̆̈̈ olan 5.sını öğrencisinin dik temel yazım çalışmalarındaki hatalarının tespit edilerek, dik temel yazım becerilerinin geliştirilmesi ve öğrencinin kazandıklar beceriyi öğretimden sonra sürdürüp sürdüremediğini, farkl ortam ve metne genelleyip genelleyemediğini ortaya koymaktır. Araştırmada nitel araştırma desenlerinden "eylem araştırması" kullanılmıştır. Araştırma verilerinin toplanabilmesi için, öğrencinin seviyesine uygun metinler, öğrencinin yazımlarım içeren defteri, uygulamacıların gözlemleri ve "Yanlış Yazım Analizi Envanteri" kullanılmıştır. Araştırmada elde edilen bulgulara göre, öğrencinin dik temel yazım becerisinin geliştiği izlenimi edinilmiştir. Ayrıca öğrencinin kazandığı dik temel harflerle yazı yazma becerisini öğretim bittikten 1, 2 ve 3 ay sonunda da sürdürdüğ̈̈ görülmüştür.
\end{abstract}

Anahtar Kelimeler: Özel öğrenme güçlüğü, yazma, dik temel yazı, eylem araştırması. 


\title{
Effects on Correcting Writing Mistakes of Students with Special Learning Disability of Vertical Writing Studies
}

\begin{abstract}
Individuals with Specific Learning Disability were placed to training environment which is suitable for their features at the end of this educational assessment process. The individuals are generally placed to inclusive education environment and they are liable to the programmes which are applied in these educational environments to which they are placed. There are academic skills mostly such as Maths, Literacy in these programmes. It is necessary to be made essential educational regulations and to be offered essential support services by considering students' features for acquisition of academic skills such as Literacy. Because one of the skills which the individuals with learning disability have difficulty at the most is skills about writing. This study aims to improve the upright writing ability of $a 5^{\text {th }}$ grade student with specific learning disability by identifying his errors in upright writing and to find out whether he can maintain and generalize this ability to different environments and texts. Study is conducted through action research one of the qualitative research methods. Texts suitable for the level of the student, student's notebook which includes his writings, observations of the implementer and "Wrong Writing Analysis Inventory" are used to collect data. As a result of the study it is found that upright writing ability of the student is improved. It is also seen that the student can maintain the writing ability at the end of $1^{\text {st }}, 2^{\text {nd }}$ and $3^{\text {rd }}$ months after.
\end{abstract}

Keywords: Specific learning disability, writing, upright writing, action research. 


\section{Giriş}

Türkiye'de okula başlayan çocuklardan beklenen önemli becerilerden birisi okuma yazmadır. Günümüze kadar okuma yazma ile ilgili farklı uygulamalar benimsenmiş ve uygulanmıştır. 2005 yılında benimsenen program geliştirme yaklaşımına bağlı olarak ses temelli okuma ve bitişik eğik yazı uygulamaları benimsenmiştir. Bu uygulamada öğrenciler yazma becerisini kazanım aşamasında bitişik eğik yazı kullanmakta, sonraki sinıflarda ise dik temel yazıya geçmektedirler. Akyol'a (2011) göre, öğrencilere ilk okuma yazma öğretimine dik temel ya da bitişik eğik harflerle başlanması gerekliliği halen tartışılan bir konudur. Bu konudaki araştırmaların kesin sonuçlar vermediği de bilinmektedir. Ayrıca MEB, 2017-2018 öğretim yılından itibaren okuma yazma öğretimi sürecinde bitişik eğik yazı uygulamasını kaldırmıştır.

Dik temel yazı, ilkokula başlayan öğrencilerin yazıyı tanımaları ve güçlüklerle karşılaşmamaları için basitleştirilmiş, dik ve yuvarlak çizgilerden oluşan harflerdir (Arslan, Aytaç ve Ilgın, 2011). Dik temel yazı, yazı öğretiminde kullanılan yazı biçimlerinden biridir Yazı ile ilgili yapılan çalışmalar arasında dik temel yazının, bitişik eğik yazının ya da iki yazının da öğretilmesi gerektiğini savunanlar bulunmaktadır (Akyol, 2011). Türkiye'de kitapların, dergilerin, bilgisayarların, levhaların v.b materyallerin dik temel harflerle yazıldığı bu yüzden öğrencilerin dik temel harfleri, bitişik eğik yazı harflerinden daha kolay öğrenebileceği düşünülebilir. Arslan ve diğerlerine (2011) göre yazı öğretiminde dik temel ya da bitişik eğik yazıdan hangisinin kullanılacağı ilköğretim programında belirtilmektedir. 1981 Türkçe programına göre ilk okuma yazma öğretimine dik temel yazı ile başlanmıştır ve ikinci sınıfın ikinci döneminden itibaren bitişik eğik yazı öğretilmiştir. 2005 İlköğretim Türkçe programında ise yazı öğretimi bitişik eğik yazı ile yapılmaktadır. Öğrenciler, bitişik eğik yazı ile yazmayı ve bitişik eğik yazıyı okumayı öğrenmektedir. Ancak kitaplar dik temel yazı ile yazıldığından, öğrencilere dik temel yazının okunuşu da öğretilmektedir. 2005 İlköğretim Türkçe programında öğrencilere dik temel yazının ne zaman ve nasıl öğretileceği ile ilgili bilgi verilmemektedir. Ülkemizde bu konuda öğretmenler arasında farklı uygulamalar olduğu görülmektedir. Öğretmenlerin uygulamalarına bakıldığında, öğretmenlerin bazılarının bitişik eğik 
yazı harfinin tanıtılmasının ardından dik temel harfleri öğrettiği, bazılarının dik temel harfleri bitişik eğik yazı harfleriyle birlikte öğrettiği ve bazı öğretmenlerinde dik temel harfleri hiç öğretmediği gözlenmektedir (Yıldırım, 2007).

Türkiye'de ilkokula başlayan tüm çocukların eğitim öğretim hizmetlerinden tam anlamıla yararlanacağı ve başarılı olacağı düşünülür. Ancak, gözle görülür bir sorun gözlenmediği halde okul yaşantısının başından itibaren öğrenmeye ilişkin sorunlar yaşayan çocuklarda vardır. Öğrenmeye ilişkin yaşanan sorunların ve okul başarısızlığının altında birçok neden bulunmaktadır (Sarı, 2003). Geçmiş yıllarda bu sorunların daha çok zihin engeli, işitme engeli, okula, aileye, çevresel-kültürel etkenlere, geçmiş yaşantılara ve çocuğun yapısal özelliklerine bağlı olduğu düşünülmekteydi. Ancak dünya da 1940'ların başından itibaren bunlardan farklı bir grubun varlığı gözlenmiştir. Zihinsel yetersizlik, sosyal/kültürel yoksunluk ve olumsuz çevresel faktörler etkili olmaksızın akademik başarıyı olumsuz etkileyen; öğrenmeye, okuma-yazma ve aritmetik becerisine ilişkin bu güçlükler, "özel öğrenme güçlüğü" adı altında ayrı ve yeni bir başlıkta değerlendirilmeye başlanmıştır (Bender, 2007). Özel öğrenme güçlüğü (ÖÖG); bireysel olarak uygulanan standart testlerde, kişinin kronolojik yaşı, ölçülen zeka düzeyi ve aldığı eğitim göz önünde bulundurulduğunda, dinleme, konuşma, okuma, yazma, sonuç çıkarma veya matematiksel yeteneklerin kazanılmasında belirgin güçlük olarak tanımlanan heterojen bir bozukluktur (Akçin, 2013; Bender, 2007; Çakıroğlu, 2015). İlker ve Melekoğlu'na göre (2017) özel öğrenme güçlüğü olan bireyler okuma bozukluğunda (disleksi) sözcük okuma, okuma doğruluğu, uyaklı okuma, heceleme, okuma akıcılığ1 ve anlamada sorunlar yaşamaktadır. Okuma güçlüğü, sadece hatalı ya da yanlış okuma olarak değil okumanın yavaşlığı, okuduğunu anlama ve anlatabilme becerisindeki yetersizlik olarak da görülebilmektedir. Özçivit-Asfuroğlu, ve Fidan'a (2016) göre, okuma güçlüğü, özel öğrenme güçlüğünün neredeyse \%90'ını oluşturan, okul çağı çocuklarının \% 1015 'inde görülen, erkeklere daha fazla rastlanan ve 'disleksi' olarak da adlandırılan alt gruptur. Özel öğrenme güçlüğü gösteren öğrencilerin sorun yaşadığı bir diğer alan ise yazma becerileridir. Alan yazında yazma güçlügüüün 'disgrafi' olarak ta adlandırıldığı bilinmektedir. Yazma problemleri de okuma da olduğu gibi farklı yönleriyle problem yaşanı- 
lan alanlardandır (Akçin, 2009). Uygun harf, hece, kelime ve cümleyi yazma problemleri ile özellikle ezbere (bakmadan) yazılması gerektiğinde harf, hece ve kelime atlama, yer değiştirme, büyük küçük harf uyu$\mathrm{mu}$, noktalama işaretleri, kurallarına uygun yazma becerilerinin birinde ya da daha fazlasında yetersizlik sergilerler. ÖÖG olan öğrencilerin yazma becerilerindeki yetersizliğin motor becerileri ile ilişkisi olabileceği de unutulmamalıdır (Demirci ve Toptaş Demirci, 2016).

$\mathrm{Bu}$ öğrencilerin yazılı ifadelerinde, yazının bütünlüğü, anlam ve içeriği bakımından da yetersizlikleri görülebilmektedir. Yazma problemleri görülen bu öğrencilerin ev ödevlerini tahtadan doğru olarak almaları, ödevlerini anlaşılır, düzgün bir biçimde yazmaları, düşünce ve duygularını ifade etme becerileri çoğunlukla akranlarından geri olduğu bilinir.

Alanyazında yazma becerilerinin öğretiminde ve geliştirilmesine yönelik bazı araştırmalar bulunmaktadır. Bu araştırmalardan birinde Yıldız (2013) yazma güçlüğü (Disgrafi) olan bir ilkokul 2. sınıf öğrencisinin el yazısı okunaklılığının geliştirilmesi amacıyla yaptığı eylem araştırmasında, yazı okunaklılı̆̆ı geliştirilen öğrencinin uygun yöntem ve tekniklerle yazma güçlüklerinin giderilebileceğini ve öğretmenlerin yazma güçlüğü olan öğrencilere destek olabileceklerini tespit etmiştir. Kaya (2016) ilkokul 4. sınıfta öğrenim gören ve yazma güçlügü olan bir öğrenciye bitişik eğik yazının öğretilmesi ve öğrencinin el yazısı okunaklılı̆̆ını geliştirmeyi amaçladığı araştırmasında görme, işitme ve zihinsel açıdan herhangi bir engeli olmadığı halde yazı yazmada sıkıntı çeken bir ilkokul öğrencisine nitel araştırma desenlerinden eylem araştırması kullanılmıştır. Çalışma sonunda, öğrencinin başlangıçta yirmi beş olan hata sayısının uygulama sonunda ikiye indiği belirlemiş, ayrıca öğrencinin yazısının da okunabilirlik bakımından kabul edilebilir bir düzeye ulaştığını görmüştür. Kodan (2016) ilkokul 3. sınıfta öğrenimine devam etmekte olan ve yazma güçlüğü yaşayan bir öğrencinin el yazısı okunaklılığını geliştirmek amacıyla yaptığı eylem araştırmasında öğrencinin yazma hatalarını belirlemiş, bu hataları gidermeye yönelik 40 saatlik bir bireysel çalışma programı hazırlanmıştır. Çalışma sonunda öğrencinin yazma hatalarında azalma ve yazı okunaklılığında gelişme olduğunu bulmuştur. Crouch ve Jakubecy (2007) yazma güçlügüne sahip özel öğrenme güçlüğü olan bir öğrencinin el yazısını, çizgi etkinlikleri ve ince motor etkinliklerinin geliştirip geliştirmediğini belirlemek amacıyla sekiz hafta 
süren çalışmasının sonucunda öğrencinin el yazısının yaklaşık \%50 oranında geliştiğini belirlemiştir. Öğretmenlerin ilkokuma yazma öğretiminde çözümleme ve ses temelli cümle yöntemleri hakkındaki görüşlerini inceleyen Tok, Tok ve Mazı (2008) dik temel harflerle yazılmış yazıların okunmasının daha kolay olduğunu bulmuşlardır. Başka bir çalışmada Arslan-Armutçu (2008) zihinsel yetersizlikten etkilenmiş öğrencilere word belgesi üzerine yazı yazma becerisinin eşzamanlı ipucu işlem süreciyle öğretiminin etkili olup olmadığını belirlemeyi amaçladığı araştırmasında, eşzamanlı ipucu işlem süreci ile yapılan öğretimin öğrencilerin Word belgesi üzerine yazı yazma becerisini kazanmalarında etkili olduğunu belirlemiştir. Ayrıca eşzamanlı ipucu işlem süreci ile yapılan öğretimin öğrencilerin kazandıkları Word belgesi üzerine yazı yazma becerisini, öğretim bittikten 7, 14, 21 gün sonra da sürdürmeleri ve farklı ortam, araç-gereç, kişi ve metne genellemeleri açısından etkili olduğunu tespit etmiştir.

Bir diğer araştırmada ise, Alyıldız (2011) ses temelli cümle yöntemi ile ilkokuma yazma öğretiminde ilköğretim birinci sını öğrencilerinin ilkokuma yazmaya başlama ve ilerleme aşamasının metin oluşturma evresinde yaptıkları sesli okuma ve yazma hatalarını belirlemeyi amaçlayan çalışmasının sonucunda, en fazla öğrenci tarafından yapılan yazma hatalarının "harfleri birbirine yakın yazma" ve "satır sonlarında uygun boşluk bırakmama" olduğu; bu hataları "kelimeler arasında az boşluk bırakma", "harfleri şekline uygun yazmama", "ayn harfi metin içerisinde farklı boyutlarda yazma" ve "harfleri birbirine uzak yazma" hatalarının izlediği görülmüştür. Erdem (2010) eğitilebilir zihinsel engelli öğrencilere okuma-yazma öğretiminde kullanılan ses temelli cümle yöntemi ve cümle çözümleme yöntemi hakkında özel eğitim alanında hizmet veren öğretmenlerin görüşlerini ortaya koymayı amaçladı̆̆ı araştırmasında, okuma-yazma öğretiminde tek düze araç-gereç ve kaynakların kullanılması, öğrencilerde problemli davranışların olması, öğrencilerde okumayazmanın ön becerilerinin gelişmemiş olması, öğrencilerin özür türü ve derecesindeki farklılıklar, okuma-yazma öğretiminde çocukların aileleri tarafından evde desteklenmediği sonuçlarına ulaşmıştır. Zihin engelli öğrencilere okuma yazma öğretiminde uygulanan cümle yöntemi ve ses temelli cümle yönteminin etkililiği hakkında öğretmen görüşlerinin belirlenmesini amaçlayan Aker (2009) ise, araştırmasının sonucunda, ses 
temelli cümle yöntemiyle yazma becerilerinin uzun zaman aldığı bedensel engelli çocuklarda güçlük yaşandığı ve el yazısında güçlük yaşandığıı, cümle yönteminde yazma becerilerinin anlamlı olduğu, hızlı olduğu fakat ezbere dayalı olduğu ve daha uzun zaman aldığını tespit etmiştir. Yazma güçlüğü olan öğrencilerin yazma becerilerini geliştirmede kopyalama metin uygulamasının ipucunun giderek artırılması yöntemiyle sunulmasının etkililiğini belirlemeyi amaçlayan Aydın ve Cavkaytar (2018) çalışmalarının sonunda yazım yanlışı yapan öğrencilerin yazım hatalarında önemli derecede azalmalar olduğunu bulmuşlardır.

İlker ve Melekoğlu (2017) ilköğretim döneminde özel öğrenme güçlüğü olan öğrencilerin yazma becerilerine ilişkin çalışmaları inceledikleri araştırmalarında ise ilköğretim döneminde öğrencilerin yaşadığı okuma yazma sorunlarının önceden belirlenip önlenmesi ya da ortaya çıtığında giderilmesi için bazı müdahalelerin gerçekleştirildiğini ve bu müdahalelerin daha çok okuma becerisi üzerinde yoğunlaştığı, yazma becerisi ile ilgili yeterli çalışmaların bulunmadığı ve mevcut çalışmaların da genellikle normal gelişim gösteren öğrenciler üzerinde yapıldığını tespit etmişlerdir. Bu bilgiler ışı̆̆ında bu araştırmanın amacı, özel öğrenme güçlüğü olan bir öğrencinin yazım hataların belirlemek ve dik temel yazı çalışmalarının yazım hatalarını düzeltme üzerindeki etkisini belirlemektir.

\section{Yöntem}

\section{Araştırmanın Modeli}

Çalışmada nitel araştırma desenlerinden eylem araştırması kullanılmıştır. Yıldırım ve Şimşek (2013) göre 'Eylem araştırmaları' uygulamada ortaya çıkan sorunların anlaşılması ve çözülmesine yönelik olarak uygulamacıların yalnız ya da bir araştırmac ile birlikte yaptığı uygulama sürecinin tamamını içerir. Bu araştırma türü sürece dayalıdır. Belirli bir konu üzerinde veri toplanması, çözüm yolunun uygulanması ve sonuçlarının değerlendirilmesi süreç içerisinde gerçekleşir. Eylem araştırmaları, uygulamada karşılaşılan sorunların araştırılmasına ve çözümlerin üretilmesine dayanır. 


\section{Katılımc1:}

Alan yazında bu tür araştırmalarda katılımcı hakkında ayrıntılı bilgi edinilmesi gerektiği belirtilmektedir Yıldız (2013) . Katılımc1, özel öğrenme güçlüğü tanısı almış, 5. Sınıfa devam eden erkek bir öğrencidir. Öğrenci, ortaokulda kaynaştırma eğitiminde devam etmekte ve haftada iki saat özel eğitim ve rehabilitasyon merkezinden destek eğitim hizmeti almaktadır. Öğrenci için 'Ali' kod adı kullanılmıştır. Öğretmenler ve aileden sıklıkla öğrencinin yazısının okunamadığı, yazım hatalarının çok olduğu, öğrencinin yazdıklarının kendisi tarafından da okunamadığı, bu durumun sınıf içi ve sınıf dışı etkinliklerde öğrenciyi olumsuz yönde etkilediği ile ilgili şikayetlerin olduğu bilgisi alınmıştır. Öğrencinin sınıf içi ve sınıf dışı yazım etkinlikleri ile ilgili defterleri incelenmiş ve sıklıkla yazım hatalarının bulunduğu belirlenmiştir. Ali'nin öğretmenleri ve velisi ile görüşülmüş defterleri incelenmiştir. Ali, ilk okuma yazmayı 2.sınıfta öğrenmiştir.

\section{Çalışma Zamanı ve Ortam:}

Çalışma, 2016-2017 eğitim öğretim yılında özel bir kurumda 26 hafta sürmüştür. Dersler haftada iki gün iki ders saati olarak yürütülmüş ve her ders 40 dakika olarak planlanmıştır. Yirmi altı haftalık süre içinde öğrencinin rahatsızlı̆̆ı nedeniyle 4 ders saati iptal edilmiş ve toplam 24 hafta, 48 ders saati uygulama gerçekleştirilmiştir. Uygulamalar, masa, sandalye, öğrenci, uygulamacı ve ders materyallerinin bulunduğu bireysel eğitim odasında yürütülmüştür. Son dört haftada ise uygulamalar farklı bir bireysel eğitim odasında gerçekleştirilmiştir.

\section{Eylem Süreci}

Çalışmalar, tablo 1'de belirtilen takvime göre yürütülmüştür. Çalışma sürecinin ilk iki haftasında (4 ders) öğrencinin yaptığı yazım hataları incelenmiştir. Öğrencinin yazım hatalarını belirlemede, sınıf içi ve sınıf dışı yazı çalışmaları ve verilen metni yazma çalışmaları incelenmiştir. Öğrencinin yazım çalışmaları ile ilgili örneklerin fotoğraflarının çekimi ve kullanımı için aileden izin alınmıştır. Öğrencinin yazı örneklerindeki 
hataları belirlemek için ise 'Yanlış Yazım Analiz Envanteri' kullanılmıştir.

Tablo 1. Çalışma Takvimi Formu

\begin{tabular}{ll}
\hline Yapılan Çalışmalar & Hafta/Ders Sayısı \\
\hline Öğrencinin Hatalarını inceleme ve & 2 hafta/4 ders \\
tespit etme çalışmaları. & \\
Öğrenci seviyesine uygun metinlerle & 2 hafta/4 ders \\
dik temel yazım becerileri farkında- & \\
lığını arttırma çalışmaları. & \\
Öğrenci seviyesine uygun metinlerle & \\
dik temel harflerin yazım çalışmaları & 6 hafta / 12 ders \\
öğretiminin yapılması. & \\
Öğrenci seviyesine uygun metinlerle & \\
dik temel harflerle kelime yazımı & 6 hafta / 12 ders \\
çalışmaları öğretiminin yapılması. & \\
Öğrenci seviyesine uygun metinlerle & \\
dik temel harflerle cümle yazımı & \\
çalışmaları öğretiminin yapılması. & 6 hafta / 12 ders \\
Öğrenci seviyesine uygun metinlerle, & \\
farklı ortam ve metne genelleme & \\
çalışmaları ile öğretim sonrası dik & 4 hafta / 12 ders \\
temel yazım becerisini sürdürüp & \\
sürdürmediğinin gözlenmesi ve \\
genel bir bakışla öğrencinin dik \\
temel yazım çalışmalarının değer- \\
lendirilmesi. \\
Toplam &
\end{tabular}

\section{Veri Toplama Araçları:}

Eylem araştırmalarında veri toplama araçları olarak gözlem, görüşme ve doküman analizleri önemli bir yer tutmaktadır (Yıldırım ve Şimşek, 2013). Bu çalışmada veriler doküman analizi, görüşme, gözlem ve Yanlış Yazım Analizi Envanteri (tablo 2) ile elde edilmiştir. Öğrencinin sınıf içi ve sınıf dışı yazı örnekleri, uygulama sırasında metin yazma etkinlikleri; öğrenci yazım hatalarını, yazım hataları sıklığını belirlemek üzere kullanılmıştır. Öğrencinin yazma etkinlikleri uygulamacılar tarafından göz- 
lenmiş ve ailenin öğrencinin yazım hataları ile ilgili görüşlerini almak üzere görüşme formu kullanılmıştır. Öğrencinin yazım hataları ise Yanlış Yazım Analizi Envanteri ile belirlenmiştir. Yanlış Yazım Analizi Envanteri ile öğrencinin yazım hataları, a) harf yazımı, b) kelime yazımı, c) cümle yazımı ve d) genel bakış olmak üzere dört alt başlıkta incelenmiştir. Harf yazımı ile ilgili 9, kelime yazımı ile 3, cümle yazımı ile 2 ve genel bakış ile ilgili 5 olmak üzere toplam 19 madde bulunmaktadır. Yanlış Yazım Analizi Envanterinin hazırlanmasında Bay (2010) Memiş ve Harmankaya (2012) Yıldız (2013) ve Kaya (2015) tarafından geliştirilen envanterlerden yararlanılmıştır. Öğrencinin genelleme becerisi için ise farklı ortamlarda, düzeyine uygun farklı metinlerle veriler toplanmıştır.

Tablo 2. Yanlış Yazım Analizi Envanteri

\begin{tabular}{lcc}
\hline Harflerin Yazımı & Evet & Hayır \\
\hline Dik temel harflerini doğru yazar. & & \\
Çizgilere dikkat eder. & & \\
Harflerin gövde kısmını doğru yazar. & & \\
Üst uzantılara dikkat eder. & & \\
Alt uzantılara dikkat eder. & & \\
Harfin başlangıç noktasına dikkat eder. & \\
Harfin bitiş noktasına dikkat eder. & \\
Yazıda harf boyutlarına dikkat eder. & \\
Büyük ve küçü̆üu yazılım olarak birbirine benzeyen harfleri doğru & \\
yazar. & & \\
\hline Kelimelerin Yazımı & Evet & Hayır \\
\hline Kelimeler arası boşluklara dikkat eder. (1 parmak boşluk kuralı) & & \\
Kelime içinde harfleri unutmaz. & \\
Kelime içinde olmayan harfleri eklemez. & Evet & Hayır \\
\hline Cümlelerin Yazımı & & \\
\hline Satır başında büyük harf kullanır. & Evet & Hayır \\
Cümleler arası uygun boşluklar bırakır. & \\
\hline Genel Bakış & & \\
\hline Paragraf başına dikkat eder. (2 parmak boşluk). & \\
Kelime bitmediğinde alt satıra geçerken heceleri uygun şekilde & \\
ayırmaya dikkat eder. & \\
Noktalama işaretlerine dikkat eder. & \\
Başlı̆ın yazımına dikkat eder. & \\
Metni yazarken metindeki satır sonuna göre defterinde de alt satıra & & \\
geçmez. & & \\
\hline
\end{tabular}




\section{Verilerin Analizi}

Bu çalışmada, Yanlış Yazım Analizi Envanteri ve uygulamacıların gözlemleri ile elde edilen veriler yüzde ve frekans ile analiz edilmiştir. Öğrencinin uygulama öncesi yanlış yazım hataları, uygulama sonrası yanlış yazım hataları karşılaştırılmıştır. Karşılaştırmada öğrenci yazım hatalarındaki değişim incelenmiştir. Yanlış yazım analizleri Yanlış Yazım Analizi Envanterine bağlı olarak harf yazımı, kelime yazımı, cümle yazımı ve genel bakış olmak üzere dört alt başlıkta analiz edilmiştir. Yazım hataları ile ilgili uygulamacıların gözlem sonuçları verilerin analizinde kullanılmıştır.

\section{Bulgular}

Özel öğrenme güçlüğü olan 5.sınıf öğrencisinin dik temel yazım çalışmalarındaki hataları tespit etmek, dik temel yazım becerilerinin geliştirilmesi ve öğrencinin kazandıkları beceriyi öğretimden sonra sürdürüp sürdürmediğini, farklı ortam ve metne genelleyip genelleyemediğini ortaya koymak amacıyla yapılan araştırmanın bulgularına aşağıda yer verilmiştir.

Araştırmamın ilk iki haftasında öğrencinin yazım hatalarını tespit etmek amacıyla öğrencinin düzeyine uygun metinler seçilmiş ve defterinin üstüne bu metinler konulduktan sonra yazması istenmiştir. Düzeltme için herhangi bir müdahalede bulunulmamıştır. Yapılan çalışma sonuçları kayıt altına alınmıştır. Şekil 1 ve Şekil 2 de öğrencinin yazım örneklerine ve yaptığı hatalara ilişkin gözlemler, uygulamalar ve yorumlara yer verilmiştir.

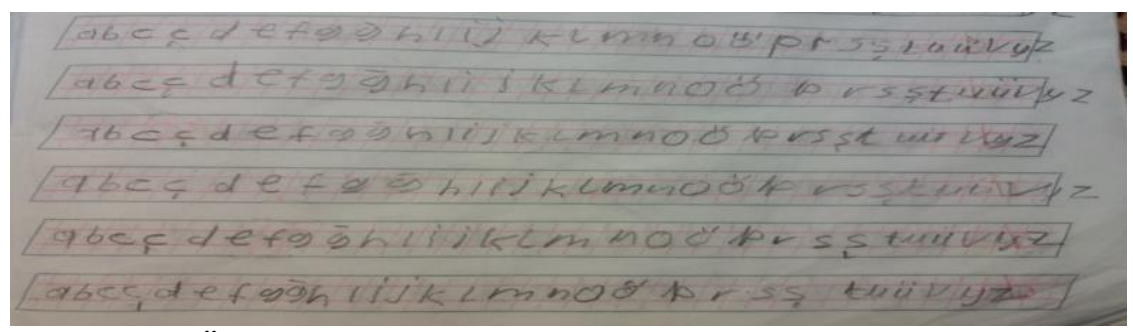

Şekil 1. Öğrencinin Alfabedeki Harfleri Dik Yazı ile Yazma Çalışması 
Şekil 1 incelendiğinde öğrencinin yazdığ harfleri satır çizgisine yerleştirmede büyük sorun yaşadığı, harflerin gövde kısımları ile alt ve üst uzantılarına dikkat etmediği, harflerin boyutlarını uygun yazmadığı ve bitişik eğik yazı ve dik temel yazıyı karışık yazdığı görülmektedir.

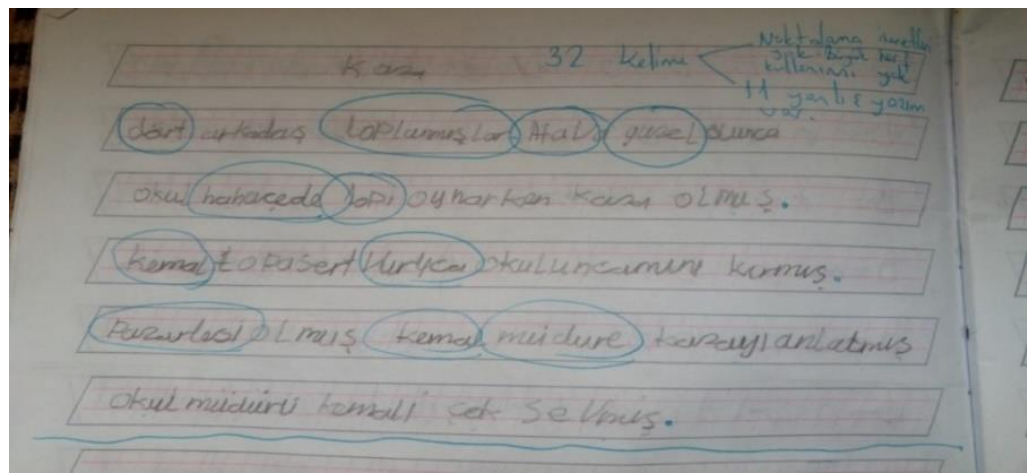

Şekil 2. Öğrencinin "Kaza" Adlı Metni Yazma Çalışması

Şekil 2 de öğrencinin defterine yazması istenen örnek bir yazı çalışması görülmektedir. Şekil 2'ye müdahale etmeden sadece önüne 12 punto Century Gothic yazı tipi ile yazılmış "Kaza" metnini bırakıp 'bu metni ve metnin içindeki harfleri olduğu gibi defterine yaz' yönergesi verilerek başka bir müdahalede bulunulmamıştır. Fakat öğrenci bitişik eğik el yazısı ile dik yazıyı birlikte kullanarak karışık yazmıştır.

Yine Şekil 2 incelendiğinde dik temel harfleri de doğru yazmadığı görülmektedir. Harflerin gövde kısımları, başlangıç noktaları, üst ve alt uzantılarına dikkat edilmeden yazıldığı tespit edilmiştir. Metni yazarken noktalama işaretlerine dikkat etmemiştir. Harflerin alt ve üst uzantılarını satır çizgilerine göre yerleştirmede çok önemli sorunlar yaşadığ 1 görülmektedir. Harflerin yazımı genel olarak değerlendirildiğinde ise harflerin büyük çoğunluğunun bitişik eğik el yazısı ile yazıldığı görülmektedir. Aşağıda 'Yanlış Yazım Analizi Envanteri'ne göre öğrencinin yazım çalışmaları değerlendirilmiştir. 
Tablo 3. Yanlış Yazım Analizi Envanteri

\begin{tabular}{|c|c|c|}
\hline Harflerin Yazımı & Evet & Hayır \\
\hline Dik temel harflerini doğru yazar. & & $\bar{X}$ \\
\hline Çizgilere dikkat eder. & & $\mathrm{X}$ \\
\hline Harflerin gövde kısmını doğru yazar. & & $X$ \\
\hline Üst uzantılara dikkat eder. & & $\mathrm{X}$ \\
\hline Alt uzantılara dikkat eder. & & $\mathrm{X}$ \\
\hline Harfin başlangıç noktasına dikkat eder. & & $X$ \\
\hline Harfin bitiş noktasına dikkat eder. & & $X$ \\
\hline Yazıda harf boyutlarına dikkat eder. & & $X$ \\
\hline $\begin{array}{l}\text { Büyük ve küçüğ̈̈ yazılım olarak birbirine benzeyen harfleri doğru } \\
\text { yazar. }\end{array}$ & & $X$ \\
\hline Kelimelerin Yazımı & Evet & Hayır \\
\hline Kelimeler arası boşluklara dikkat eder. (1 parmak boşluk kuralı) & & $\mathrm{X}$ \\
\hline Kelime içinde harfleri unutmaz. & & $\mathrm{X}$ \\
\hline Kelime içinde olmayan harfleri eklemez. & & $x$ \\
\hline Cümlelerin Yazımı & Evet & Hayır \\
\hline Satır başında büyük harf kullanır. & & $x$ \\
\hline Cümleler arası uygun boşluklar bırakır. & & $\mathrm{X}$ \\
\hline Genel Bakış & Evet & Hayır \\
\hline Paragraf başına dikkat eder. (2 parmak boşluk). & & $\mathrm{X}$ \\
\hline $\begin{array}{l}\text { Kelime bitmediğinde alt satıra geçerken heceleri uygun şekilde } \\
\text { ayırmaya dikkat eder. }\end{array}$ & & $\mathrm{X}$ \\
\hline Noktalama işaretlerine dikkat eder. & & $\mathrm{X}$ \\
\hline Başlığın yazımına dikkat eder. & & $\mathrm{X}$ \\
\hline $\begin{array}{l}\text { Metni yazarken metindeki satır sonuna göre defterinde de alt satıra } \\
\text { geçmez. }\end{array}$ & & $X$ \\
\hline
\end{tabular}

Öğrencinin yaptığı hatalar tespit edildikten sonra, dik temel yazı farkındalığını arttıracak etkinlikler yapılmıştır. Örneğin; "Kaza" metnini Century Gothic yazı tipi 12 punto ile kırmızı kalemle yazıp bu metindeki harflerin üzerinden giderek yazdıılmıştır. Ayrıca 2 hafta (4 ders) boyunca öğrencinin seviyesine uygun dik temel harflerle yazılmış metinler yazdırılmıştır. Aşağıda iki hafta sonunda öğrencinin dik temel harflerle yazma çalışmalarında farkındalığının arttığını gösteren şekil 3'e yer verilmiştir. 


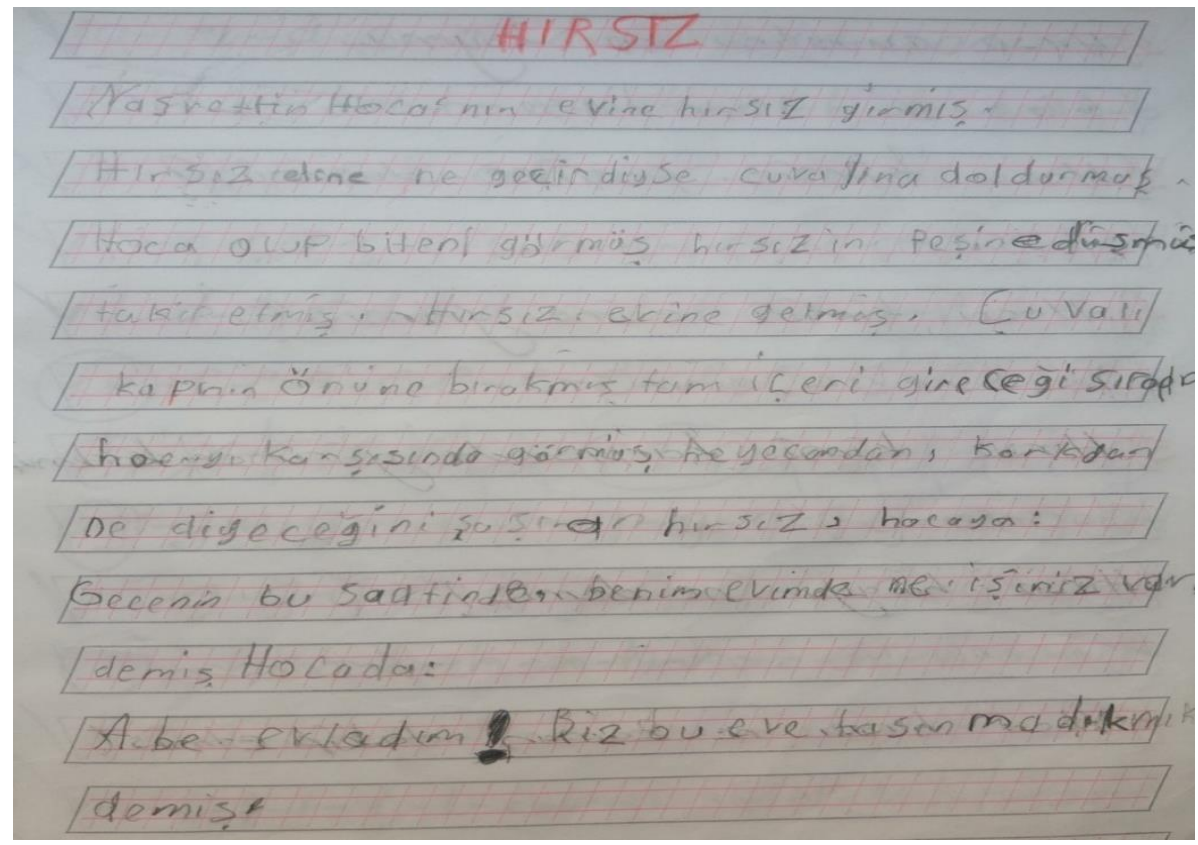

Şekil 3. Öğrencinin "Hırsız" Adlı Metni Yazma Çalışması

Şekil 3 incelendiğinde öğrencinin dik yazı ile yazma farkındalığı kazandığ1 görülmektedir. Dik yazı ile yazma farkındalığı kazandığı için öğretime başlanabileceği öngörülmüştür.

Öğretim sürecinde öğrenci ile büyük ve küçük dik temel harflerin yazımı, çizgilere, alt ve üst uzantılara dikkat etme, başlangiç ve bitiş noktaları, harf ve kelime aralarına uygun boşluk bırakma, harf unutma ve ekleme, satır başında büyük harf kullanma, noktalama işaretleri ve alt satıra geçerken hece bölme çalışmaları yoğun bir şekilde açık anlatım yöntemi ile çalışılmıştır.

Öğretim süreci altı hafta süren çalışmalarımızda öğrencinin küçük ve büyük dik temel harflerde yaptığı yanlışları tespit etmek için hata tespit formu kullanılmıştır. Aşağıda hata tespit formuna göre öğrencinin dik temel harfleri yazma becerisindeki hata sayıları yüzde olarak verilmiştir. 
Tablo 4. Dik Temel Harf Hata Tespit Formu

\begin{tabular}{|c|c|c|c|}
\hline $\begin{array}{l}\text { Harfler Doğru } \\
\text { Yazım Oranı }\end{array}$ & $\%$ & $\begin{array}{l}\text { Harfler Doğru } \\
\text { Yazım Oranı }\end{array}$ & $\%$ \\
\hline $\mathbf{a}$ & 80 & $\mathrm{~m}$ & 80 \\
\hline $\mathbf{b}$ & 17 & $\mathrm{n}$ & 89 \\
\hline c & 83 & o & 95 \\
\hline ç & 82 & $\ddot{o}$ & 92 \\
\hline d & 20 & $\mathrm{p}$ & 14 \\
\hline e & 91 & $\mathrm{r}$ & 84 \\
\hline f & 10 & $\mathrm{~s}$ & 88 \\
\hline $\mathrm{g}$ & 13 & Ş & 86 \\
\hline$\breve{\mathbf{g}}$ & 12 & $t$ & 24 \\
\hline h & 21 & $\mathrm{u}$ & 90 \\
\hline 1 & 85 & $\ddot{\mathrm{u}}$ & 88 \\
\hline $\mathbf{i}$ & 83 & $\mathrm{v}$ & 80 \\
\hline $\mathbf{j}$ & 10 & $\mathrm{y}$ & 15 \\
\hline $\mathbf{k}$ & 5 & $\mathrm{z}$ & 96 \\
\hline 1 & 40 & & \\
\hline
\end{tabular}

Harflerin yazımını öğretirken ilk etkinliğimiz gövde kısmından oluşan harflerin öğretimidir. Çünkü alt ve üst uzantıların yazımında kılavuz çizgilerine dikkat etmemektedir. Öncelikle sadece gövdeden oluşan harflerin kılavuz çizgisine dikkat ederek doğru yazma çalışmaları yapılmıştır. Sadece gövdeden oluşan harflerin öğretimini yaptıktan sonraki performansı için Tablo 4 incelendiğinde alt veya üst uzantısı olmayan gövdeden oluşan harflerin $(\mathrm{a}, \mathrm{c}, \mathrm{c}, \mathrm{e}, \mathrm{l}, \mathrm{i}, \mathrm{m}, \mathrm{n}, \mathrm{o}, \mathrm{o}, \mathrm{r}, \mathrm{s}, \mathrm{s}, \mathrm{u}, \mathrm{u}, \mathrm{v}, \mathrm{z})$ ortalama \%87 doğrulukla yazıldığı tespit edilmiştir. Alt veya üst uzantısı olan harfle$\operatorname{rin}(\mathrm{b}, \mathrm{d}, \mathrm{f}, \mathrm{g}, \breve{\mathrm{g}}, \mathrm{h}, \mathrm{j}, \mathrm{k}, \mathrm{l}, \mathrm{p}, \mathrm{t}, \mathrm{y})$ ortalama \%17 doğrulukla yazıldığ1 tespit edilmiştir.

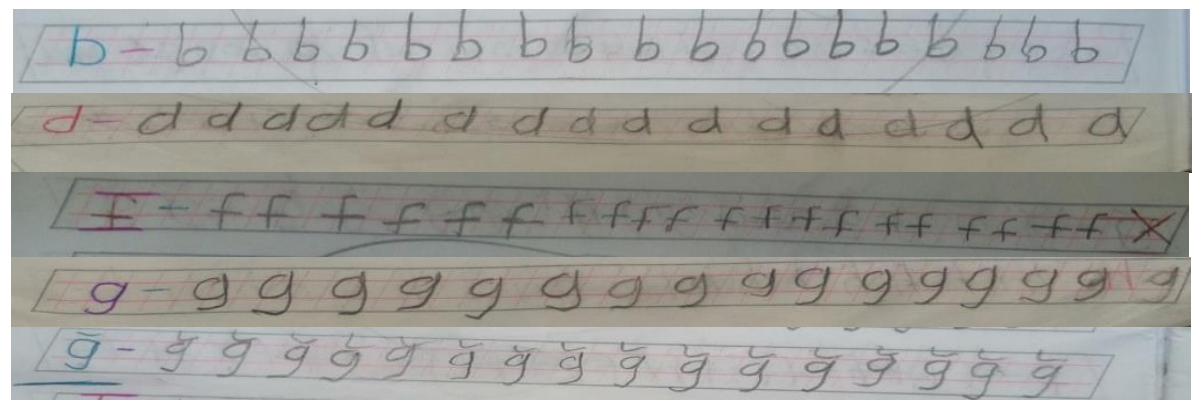




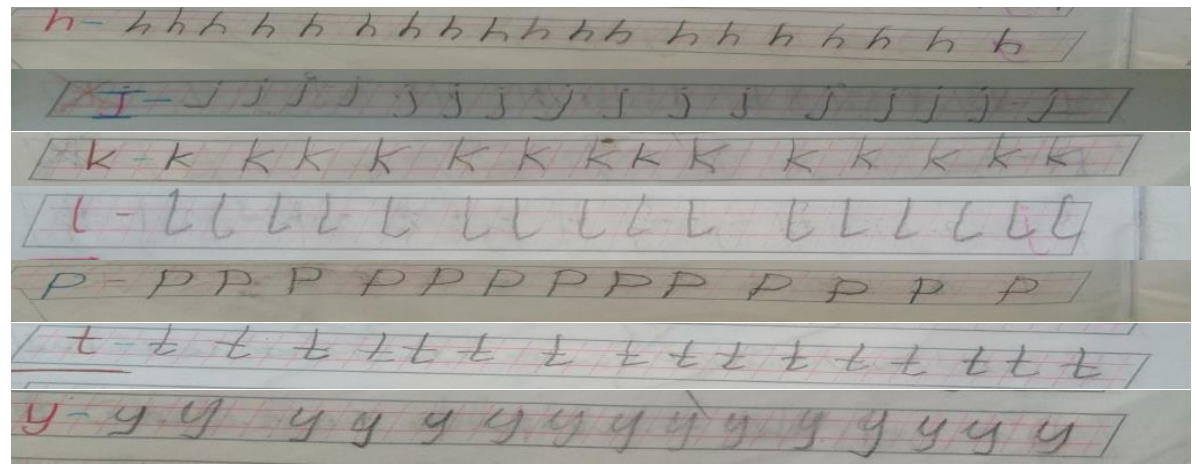

Şekil 4. Alt ve Üst Uzantısı Olan Harflerin Yazımı

Şekil 4 alt ve üst uzantısı olan harflerin dik yazı ile doğru yazımına ilişkin etkinlik çalışmamızdır. Öğretim aşamasında öğrenciye ipucu niteliğinde renkli kalem ile kılavuz çizgileri çizilmiştir. Bu ipucunda kılavuz çizgilerine dikkat edilmeyen harfler yuvarlak içine alınarak öğrenciye yanlış yazdığının farkında olması sağlanmıştır. Oturum sonuna kadar öğrenci edinim aşamasını tamamladığ 1 harfler için ev ödevi verilerek evde hiç kimseden yardım almadan tek başına yapması sağlanarak kalıcılık sağlanmıştır (Öğrencinin harf yazımında akıcılık aşaması gayet uygundur). Öğrenci oturum sonuna kadar tamamlayamadığı harfler için silikleştirme soluklaştırma tekniği uygulanarak doğru yazması sağlanmıştır. Öğretim sonunda harflerin doğru yazım oranı \%94 seviyesine ulaşmıştır.

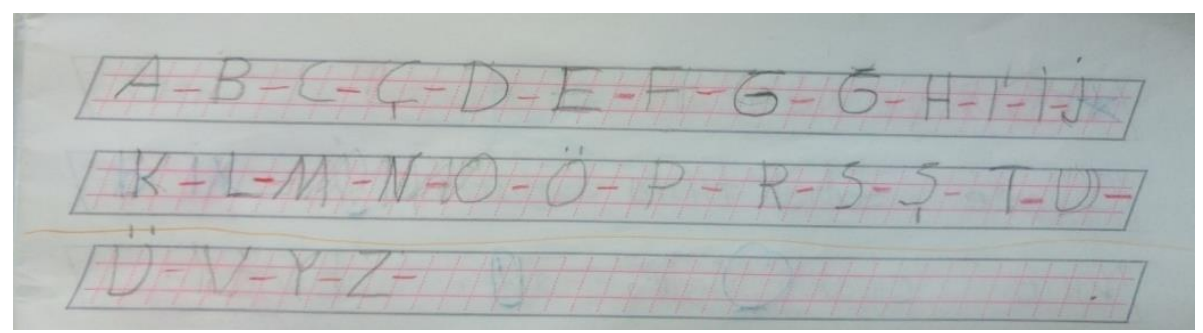

Şekil 5. Büyük Dik Harflerin Yazımı

Şekil 5 incelendiğinde küçük dik harflerin doğru yazımından sonra büyük dik harflerin öğretimi de tamamlanmıştır. Bu öğretim sonunda 
öğrencinin kılavuz çizgilerine, alt ve üst uzantılarına, harflerin başlangıç ve bitiş noktaları ile çizim yönlerine dikkat ederek yazdığ görülmektedir.

Öğretim etkinliğimiz her harfi 100'er defa yazdırarak 15 sayfa sürmüştür ve 2 hafta çalışılmıştır. Tekrar bütün alfabedeki dik temel harflerin hepsi yüzer defa yazdırılarak performansını aldığımızda oluşan tablo aşağıdaki gibi çıkmıştır.

\begin{tabular}{|c|c|c|c|}
\hline $\begin{array}{l}\text { Harfler Doğru Yazım } \\
\text { Oranı }\end{array}$ & $\%$ & $\begin{array}{l}\text { Harfler Doğru Yazım } \\
\text { Oranı }\end{array}$ & $\%$ \\
\hline $\mathbf{a}$ & 98 & $\mathrm{~m}$ & 100 \\
\hline b & 95 & $\mathrm{n}$ & 100 \\
\hline c & 98 & o & 100 \\
\hline ç & 96 & $\ddot{o}$ & 99 \\
\hline d & 94 & $\mathrm{p}$ & 94 \\
\hline e & 97 & $\mathrm{r}$ & 98 \\
\hline f & 85 & $\mathrm{~s}$ & 99 \\
\hline $\mathrm{g}$ & 90 & ş & 97 \\
\hline$\breve{\mathrm{g}}$ & 87 & $\mathrm{t}$ & 86 \\
\hline h & 90 & $\mathrm{u}$ & 100 \\
\hline 1 & 95 & $\ddot{\mathrm{u}}$ & 97 \\
\hline i & 94 & $\mathrm{v}$ & 100 \\
\hline j & 100 & $\mathrm{y}$ & 100 \\
\hline k & 82 & $\mathrm{z}$ & 98 \\
\hline 1 & 98 & & \\
\hline
\end{tabular}

Tablo 5 incelendiğinde alt veya üst uzantısı olmayan gövdeden oluşan harflerin $(\mathrm{a}, \mathrm{c}, \mathrm{c}, \mathrm{e}, \mathrm{l}, \mathrm{i}, \mathrm{m}, \mathrm{n}, \mathrm{o}, \mathrm{o}, \mathrm{r}, \mathrm{s}, \mathrm{s}, \mathrm{u}, \mathrm{u}, \mathrm{v}, \mathrm{z})$ ve alt veya üst uzantısı olan harflerin $(b, d, f, g, \breve{g}, h, j, k, l, p, t, y)$ ortalama \%95 doğrulukla yazıldığ1 tespit edilmiştir.

Öğretim aşaması altı hafta süren çalışmalarımızın son haftasında öğrencinin dik temel harflerle yazdığı metinlerdeki harflerin yazımını tablo 6 ' da yanlış yazım analizi envanterinin harflerin yazımına göre değerlendiren uygulamacılar, öğrencinin dik temel harflerde belirli başarı ve olgunluğa ulaştığına karar vererek kelimelerin yazımı çalışmalarına geçmeye karar vermişlerdir. 
Tablo 6. Yanlış Yazım Analizi Envanteri

\begin{tabular}{|c|c|}
\hline Harflerin Yazımı & Evet Hayır \\
\hline Dik temel harflerini doğru yazar. & $\mathrm{X}$ \\
\hline \multicolumn{2}{|l|}{ Çizgilere dikkat eder. } \\
\hline Harflerin gövde kısmını doğru yazar. & $X$ \\
\hline Üst uzantılara dikkat eder. & $X$ \\
\hline Alt uzantılara dikkat eder. & $X$ \\
\hline Harfin başlangiç noktasına dikkat eder. & $X$ \\
\hline Harfin bitiş noktasına dikkat eder. & $x$ \\
\hline Yazıda harf boyutlarına dikkat eder. & $X$ \\
\hline Büyük ve küçüğü yazılım olarak birbirine benzeyen harfleri doğru & $X$ \\
\hline yazar. & $X$ \\
\hline
\end{tabular}

Öğrencinin kazandığı dik temel harflerle yazım becerilerini öğretimden sonra altı hafta kelimelerin yazımı çalışmaları yapılmıştır. Bu çalışmalarda, kelimeler arası uygun boşluk bırakma, kelime içindeki harfleri eksiksiz yazma ve kelime içinde olmayan harf eklememe çalışmaları üzerinde durulmuştur. Kelimelerin yazımı ile ilgili yapılan çalışmalardan biri örnek olarak şekil 6'da verilmiştir.

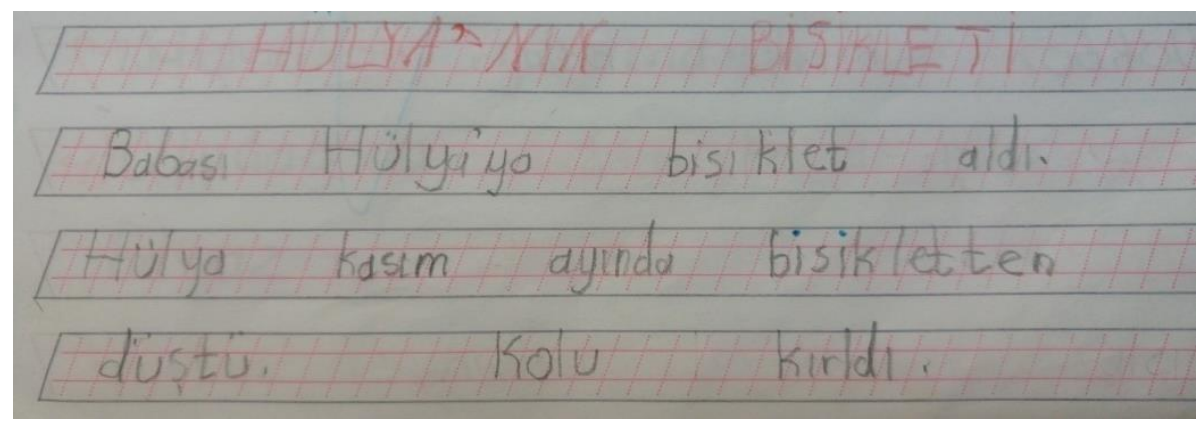

Şekil 6. “Hülya'nın Bisikleti” Metni Dik Temel Harflerle Yazım Çalışması

Şekil 6 incelendiğinde, öğrenci kelimeler arası uygun boşluklar b1rakmamıştır. "kırıldı" kelimesindeki " 1 " sesini yazmayı unutmuştur. Kelimeler içinde bulunmayan harf ekleme ise yapılmamıştır. Altı hafta süren kelime yazımı çalışmaları yanlış yazım analizi envanterine göre uygulamacılar tarafından değerlendirilerek sonuçlar tablo 7 de verilmiştir. 
Tablo 7. Yanlış Yazım Analizi Envanteri

\begin{tabular}{lcc}
\hline Kelimelerin Yazımı & Evet & Hayır \\
\hline $\begin{array}{l}\text { Kelimeler arası boşluklara dikkat eder. (1 parmak boşluk } \\
\text { kuralı) }\end{array}$ & $\mathrm{X}$ \\
$\begin{array}{l}\text { Kelime içinde harfleri unutmaz. } \\
\text { Kelime içinde olmayan harfleri eklemez. }\end{array}$ & $\mathrm{X}$ \\
\hline
\end{tabular}

Tablo 7 incelendiğinde öğrencinin kelimeler arası uygun boşluk bırakma ve kelimeler içindeki harfleri unutma sorunlarının devam ettiği ancak kelimelerde olmayan harf ekleme sorununun ortadan kalktığ görülmektedir.

Öğrenci ile altı hafta süren kelimelerin yazımı çalışmalarından sonra altı hafta cümle yazımı çalışmaları yapılmıştır. Cümle yazımı çalışmalarında, satır başlarında büyük harf kullanma ve cümleler arası uygun boşluk bırakma çalışmaları üzerinde durulmuştur. Cümle yazımı ile ilgili yapılan çalışmalardan biri örnek olarak şekil 7'de verilmiştir.

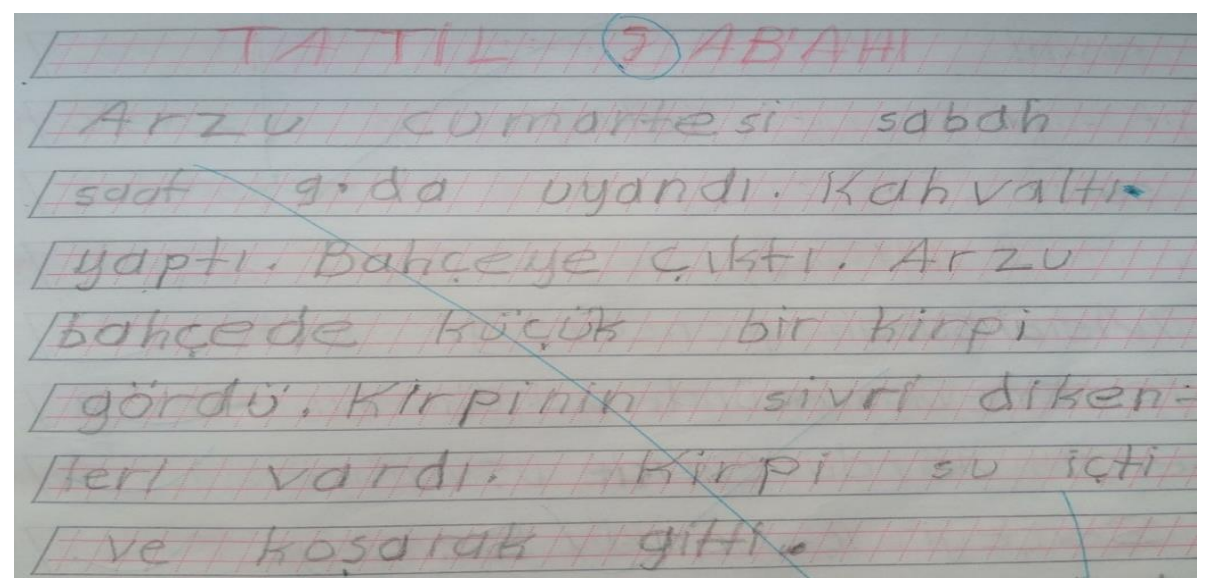

Şekil 7. “Tatil Sabahı" Metni Dik Temel Harflerle Yazım Çalışması

Şekil 7 incelendiğinde öğrencinin satır başlarında büyük harf kullandığı fakat cümleler arası uygun boşluklar bırakmadığı görülmektedir. Altı hafta süren cümle yazımı çalışmaları yanlış yazım analizi envanterine göre uygulamacılar tarafından değerlendirilerek sonuçlar tablo 8 de verilmiştir. 
Tablo 8. Yanlış Yazım Analizi Envanteri

\begin{tabular}{lcc}
\hline Cümlelerin Yazımı & Evet & Hayır \\
\hline $\begin{array}{l}\text { Satır başında büyük harf kullanır. } \\
\text { Cümleler arası uygun boşluklar bırakır. }\end{array}$ & $X$ & \\
& & $X$ \\
\hline
\end{tabular}

Tablo 8 incelendiğinde öğrencinin, satır başlarında büyük harf kullanmaya başladığı fakat cümleler arası uygun boşluk bırakmadığı görülmektedir.

Öğrenci ile altı hafta süren cümlelerin yazımı çalışmalarından sonra dört hafta öğrencinin dik temel yazım çalışmaları farklı metin ve ortamlarda yürütülmüştür. Genel bakışla da öğrencinin dik temel yazım çalışmalarına devam edilmiştir. Genel bakışta öğrencinin yazım çakışmaları paragraf başında boşluk bırakma, alt satıra geçerken heceyi uygun bölme, noktalama işaretleri, başlığın yazımı ve metindeki satır sonuna göre defterin alt satırına geçilmemesi gerektiği konuları üzerinde durulmuştur. Dört hafta süren bu çalışmalarda öğrencinin dik temel yazım becerisini sürdürüp sürdürmediği uygulamacılar tarafından dikkatle gözlemlenmiştir. Genel bakışla ilgili yapılan çalışmalardan biri örnek olarak şekil 8 de verilmiştir.

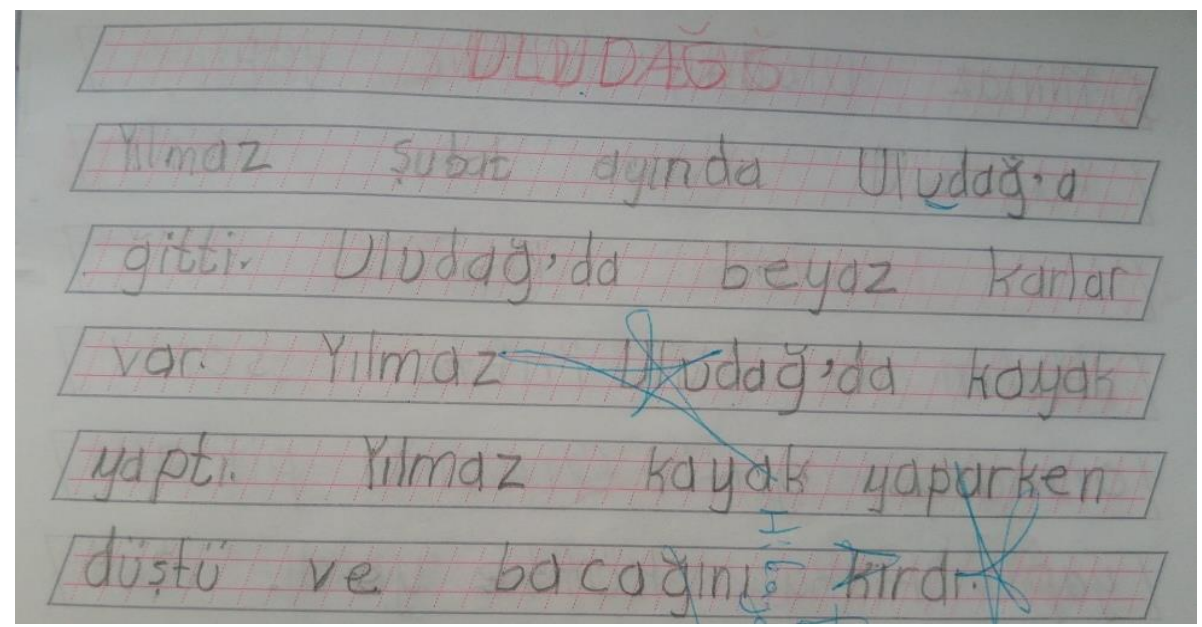

Şekil 8. “Uludă̆" Metni Dik Temel Harflerle Yazım Çalışması 
Şekil 8 incelendiğinde öğrenci, noktalama işaretlerine ve başlığın yazımına dikkat etmiştir. Paragraf başına dikkat etmemiştir. Metni yazarken metindeki satır sonuna göre defterinde de alt satıra geçmemiştir. Dört hafta süren genel bakış çalışmaları yanlış yazım analizi envanterine göre uygulamacılar tarafından değerlendirilerek sonuçlar Tablo 9 da verilmiştir.

Tablo 9. Yanlış Yazım Analizi Envanteri

\begin{tabular}{llc}
\hline Genel Bakış & Evet & Hayır \\
\hline Paragraf başına dikkat eder. (2 parmak boşluk). & & $\mathrm{X}$ \\
$\begin{array}{l}\text { Kelime bitmediğinde alt satıra geçerken heceleri uygun } \\
\text { şekilde ayırmaya dikkat eder. }\end{array}$ & \\
Noktalama işaretlerine dikkat eder. & $\mathrm{X}$ & \\
Başlığın yazımına dikkat eder. & $\mathrm{X}$ \\
$\begin{array}{l}\text { Metni yazarken metindeki satır sonuna göre defterinde de } \\
\text { alt satıra geçmez. }\end{array}$ & $\mathrm{X}$ \\
\hline
\end{tabular}

Tablo 9 incelendiğinde öğrencinin paragraf başında uygun boşluk b1rakmadığı fakat noktalama işaretleri, başlığın yazımı, alt satıra geçerken kelimeleri uygun şekilde hecelerine ayırma ve metindeki satır sonuna göre defterinde alt satırına geçmediği görülmektedir.

Öğrenci ile sürdürülen yirmi altı haftalık çalışmalar sonunda uygulamacılar, öğrencinin dik temel harflerle yazım çalışmalarında büyük ilerlemeler kaydettiğini, dik temel harflerle farklı ortamlarda ve farklı metinlerle de öğrendiklerini sürdürdüğünü gözlemlemişlerdir.

\section{Tartışma}

Özel öğrenme güçlüğü çeken öğrencilerin ortaokulda yazılarındaki tutarsızlık ve olumsuzluklar nedeniyle dik temel yazı kullanımı öğretimi büyük önem arz ettiği bilinmektedir. Bu bilgiden hareketle ilkokulda bitişik eğik yazıyı öğrenen özel öğrenme güçlüğü olan öğrencilerin ortaokula geçişte çok zorlandıkları görülebilmektedir. Çünkü özel öğrenme güçlüğü olan öğrencilerin tamamı kaynaştırma öğrencisidir ve bu öğrencilerin ortaokulda akademik alanlardaki sorunları artmaktadır. Bu sorunlar ilkokul öğretmenlerinin onlara bitişik eğik el yazısını öğretmesinden sonra temel dik yazıyı öğretmemelerinden dolayı kaynaklanabilir. 
Özel öğrenme güçlüğü çeken öğrencileri kaynaştırmaya dahil edilmesinin amacı günlük hayata uyum sağlayabilen bireyler olarak yaşamalarıdır. Bu bağlamda günlük hayatta bitişik eğik el yazısı yöntemi özel öğrenme güçlüğü çeken bireyler için ilkokuldan öteye gitmeyebilir. Özel öğrenme güçlügü olan kaynaştırma öğrencileri için ilkokul öğretmenleri tarafından Bireyselleştirilmiş Eğitim Planı'na temel dik yazının öğretimini almaları onların hayatını kolaylaştırması ve günlük hayata daha çabuk uyum sağlayacağı düşünülerek yer almasının sağlanması bu öğrenciler için faydalı olabilir.

Özel öğrenme güçlüğü olan bir öğrencinin yazım hatalarını belirlemek ve dik temel yazı çalışmalarının yazım hatalarını düzeltme üzerindeki etkisini ortaya koymak amacıyla yapılan bu araştırmanın bulguları alan yazını ile karşılaştırıldığında Yıldız’ın (2013) yazma güçlüğü (Disgrafi) olan bir ilkokul 2. sınıf öğrencisinin el yazısı okunaklılığının geliştirilmesi amacıyla yaptığı eylem araştırmasında, özel öğrenme güçlüğü olan öğrenci ile uygun yöntem ve tekniklerle yazma çalışmalarının yazma güçlüklerini giderilebileceği ve bu konuda öğretmenlerin yazma güçlüğü olan öğrencilere destek olabildiklerini gösteren araştırma sonuçları ile benzerlik göstermektedir. Ayrıca Kaya'nın (2015) ilkokul 4. sınıfta öğrenim gören ve yazma güçlüğü olan bir öğrenciye bitişik eğik yazının öğretilmesi ve öğrencinin el yazısı okunaklılığının geliştirilmesini amaçladığı, uygun yöntem ve teknikler belirlenip kullanıldığında yazma güçlüklerinin giderilebileceği, yazı okunaklılı̆̆ının artırılabileceği, yazı problemi ve yazma güçlüğü olan öğrencilerle birebir çalışmanın oldukça etkili olduğu ve bu öğrencilere sinıf düzeyine uygun yazma becerisinin kazandırılmasının mümkün olduğu çalışma sonuçları ile de paralellik göstermektedir. Bunların yanısıra Kodan'ın (2016) yazım güçlüğü olan öğrenciyle yaptığı eylem araştırması ve Kuşdemir, Kurban ve Bulut'un (2018) yazma güçlüğü olan bir öğrenci ile yaptıkları eylem araştırmas1nın bulguları ile bu araştırma bulgularının benzerlik gösterdiği görülmüştür.

Bunların yanı sıra Akyol'un (2005) okuma yazma öğretiminde bireysel farklılıkları göz önünde bulundurmak gerekir ifadesinden hareketle özel öğrenme güçlüğü ve diğer kaynaştırma öğrencilerinde normal öğrencilerden farklı bir yöntem uygulanabileceğini de söylemek mümkündür. Nitekim, Aydın ve Cavkaytar'ın (2018) yazma güçlüğü olan öğren- 
cilerin el yazısı okunaklılığının geliştirilmesinde ipucunun giderek artırılması uygulamasıyla elde ettikleri sonuçlarda öğrencilerin yazım becerilerinde gelişmeler olduğu görülmüştür.

\section{Sonuç}

Özel öğrenme güçlüğü olan 5. sınıf öğrencisinin dik temel yazım çalışmalarındaki hatalarını tespit etmek, dik temel yazım becerilerinin geliştirilmesi ve öğrencinin kazandıkları beceriyi öğretimden sonra sürdürüp sürdürmediğini, farklı ortam ve metne genelleyip genelleyemediğini ortaya koymak amaciyla yapılan bu araştırmada sonuç olarak, öğrencinin dik temel yazım becerisinin geliştiği izlenimi edinilmiştir. Ayrıca öğrencinin kazandığı dik temel harflerle yazı yazma becerisini öğretim bittikten 1, 2 ve 3 ay sonunda da sürdürdüğü, farklı ortam ve metne de genellediği görülmüştür. Ayrıca derslerde kullanılan temel dik yazı yöntemini öğrenen özel öğrenme güçlüğü çeken bu kaynaştırma öğrencisinin bilgi ve becerileri daha kolay edinmede, edinilen bilgi ve becerilerinin kalıcı olmalarına ve öğrencinin dikkat ve motivasyonunu olumlu yönde etkilediği de araştırma sürecinde gözlenmiştir.

Araştırmada elde edilen bulgular ve sonuçlar ışığında şu öneriler yapilabilir.

1. Özel öğrenme güçlüğü olan öğrencilerde dik temel yazı biçiminin Bireyselleştirilmiş Eğitim Planı'na dahil edilerek öğretilmesi öğrencilerin eğitim öğretimlerinde ve gelecek hayatlarında daha başarılı ve toplumla daha uyumlu olmasını sağlayabilir.

2. Özel öğrenme güçlüğü olan öğrencilerin ilkokuldan ortaokula geçerken hazırlanması için temel dik yazının öğretimi derslerindeki başarılarını artırabilir.

3. Özel öğrenme güçlüğü olan öğrenciler için bitişik eğik yazı ve dik temel yazı öğretimlerinden hangisinin bireye daha fazla katkı sağladı̆̆ı yönünde ileri araştırmalar yapılabilir. 


\title{
EXTENDED ABSTRACT
}

\section{Effects on Correcting Writing Mistakes of Students with Special Learning Disability of Vertical Writing Studies}

\author{
Yahya Çıkılı - Serdal Deniz - Hüseyin Barış Kaya \\ Necmettin Erbakan University/Ministry of National Education
}

In the world since the early 1940s, difficulties which affect academic achievement negatively without effective to mental deficiency, social and cultural deprivation and negative environmental factors; and related to learning, reading, writing and arithmetical skills (the three R's) has been started to be evaluated under the name of "specific learning disability" as a distinct and new title. (Bender, 2007). Considering one's chronological age, measured IQ (intelligence level) and education in standardized tests which are applied individually, specific learning disability is a heterogenic disability which is defined as a distinct difficulty in listening, speaking, reading, writing, inference or acquisition of mathematical skills. (Bender, 2007; Akçin, 2013; Çakıroğlu, 2015).At the end of educational diagnosis and evaluation process, the students who are determined to have specific learning disability are directed to inclusive education. Because the implementations of inclusive education are training environments which facilitate the students to perform themselves at utmost level. Those who are determined to be in inclusive education follow the general education programmes which are applied in their new class and the education should be individualised. In these education programmes -in addition to the other skills- it is also given some lessons about academic skills to the students and one of them is Turkish Lesson. One of the basic academic skills which are intended to give the students during elementary schools is literacy (reading/writing) skill. It is adopted the implementations of oral reading and running hand which are based on program development approaches created in 2005.In this implemen- 
tation the students use running hand as a process in the acquisition of writing skill, but in the next grades they use perpendicular writing. According to Akyol (2011), it is still controversial that it is necessary for the students to start first literacy (reading/writing) education with perpendicular writing or running hand. It is also known that researches about this topic are not certain. Besides, just after academic year of 2017-2018, MEB abolished the implementation of running hand in literacy education. Prose writing includes the letters which was simplified for the students who start to elementary school in order to recognize writing and not encounter difficulties and these letters consist of perpendicular and round lines. (Arslan, Aytaç and Ilgın, 2011).Among the researches about writing there are some people defending that it is necessary to teach perpendicular writing, running hand or both of them. (Akyol, 2011). In Turkey people may think that materials such as books, magazines, computers, sheets etc. are written with perpendicular basic letters and so students can learn these letters more easily than adjoin italic ones. The research aims to determine misspellings of a student who has specific learning disability and perpendicular writing works' effect on correcting these misspellings.

\section{Method}

In this study, action research which is one of the qualitative research methods was used. This research is based on process. Collecting data on a specific topic, implementing a solution and evaluating results form in a process. This study lasted for 26 weeks in a private firm in academic year of 2016-2017. Lessons were taught in two days and two periods a week and each period lasted forty minutes. In first two weeks of the study process (four lessons) misspellings which students made were examined. Mispellinator (The Inventory of Misspelling Analysis) was used for determining misspellings of a student through his/her writing sample. In this research, datas were collected by document analysis, interview, observation and Mispellinator. Students' writing sample inside class and 
outside class, writing exercises during the implementation were used for determining students' misspellings and these misspellings' frequency. Writing exercises of students were observed by implementers and meeting forms were used for learning the families' opinions about their children's misspellings. Students' misspellings were determined by Misspellinator. Because of Misspellinator, student's misspellings were examined under four bottom booms.
A- Letter spelling
B- Word spelling
C- Sentence spelling
D- Overview

Student's misspellings before implementation were compared with those after implementation. In this comparison, changes in misspellings were examined.

Misspelling Analysis were analysed under four bottom booms which are letter spelling, word spelling, sentence spelling and overview.

\section{Findings, Discussion and Results}

The faults which students made were determined by Misspellinator and it was found that students misspelled letters, words and sentences. At the end of the action process it was understood that students prominently developed themselves about spelling of letters, words and sentences. When compared the findings of this research with body of literature, Yildiz's action research (2013) about elementary school second grade student with writing disability (Disgrafi) -which he aimed to develop his/her(the student) handwriting readability- is similar with the results of research that writing disability of a student who has specific learning disability could be removed and teachers could support these students. Also Kaya's (2015) aim to teach running hand a student with writing disability and studying in elementary fourth grade and aim to develop the student's handwriting readability is parallel with the results of study that when used true method and techniques writing disabilities could 
remove, writing readability could increase, studying individually with the students who have writing disability could be quite effective and gaining these students to writing skill in class level could be possible. Consequently, in this research the development of students' perpendicular writing skills was observed. Also, it was observed that writing skills with perpendicular letters which students gained lasted for one, two and three months even after the education finished. And it included in different environments and contexts.

\section{Kaynakça / References}

Akçin, N. (2009). Öğrenme güçlüğü gösteren çocukların yazma sürecinde gösterdiği özellikler. M.Ü. Atatürk Ĕgitim Fakültesi Ĕ̆itim Bilimleri Dergisi, 29, 5-18.

Akçin, N. (2013). Özel öğrenme güçlüğ̈̈̈ olan çocuklar. (Ed. Vuran, S.). Özel Ĕ̆gitim. Ankara: Maya Akademi.

Aker, Z. (2009). Zihinsel engelli öğrencilere okuma yazma öğretiminde kullamlan ses temelli cümle yöntemi ile cümle yönteminin etkililiğine ilişkin öğretmen görüşlerinin belirlenmesi. (Yayınlanmamış Yüksek Lisans Tezi) Abant İzzet Baysal Üniversitesi Sosyal Bilimler Enstitüsü, Bolu.

Akyol, H. (2011). Türkçe ilk okuma - yazma öğretimi. Ankara: Pegem A Yayıncllik.

Akyol, H. ve Temur, T. (2008). Ses temelli cümle yöntemi ve cümle yöntemi ile okuma yazma öğrenen öğrencilerin okuma becerilerinin öğretmen görüşlerine göre değerlendirilmesi. Mustafa Kemal Üniversitesi Sosyal Bilimler Enstitüsü Dergisi, 5 (9), 79-95.

Alyıldız, A. (2011). Ses temelli cümle yöntemi ile ilkokuma yazma öğretiminde ögrenci hatalarmın incelenmesi. (Yayımlanmış Yüksek Lisans Tezi) Marmara Üniversitesi Eğitim Bilimleri Enstitüsü, İstanbul.

Arslan, D.,Aytaç A. ve Ilgın H. (2011) İlköğretim birinci sınıf öğrencilerinin yazı biçimlerine (Dik Temel Yazı Ve Bitişik Eğik Yazı) göre okuma düzeyleri. New World Sciences Academy Education Sciences, 6 (2), 1422-1434. 
Arslan-Armutçu, O. (2008). Zihinsel yetersizlikten etkilenmiş öğrencilere word belgesi üzerine yazı yazma becerisinin kazandırlmasında eşzamanlı ipucu işlem süreci ile yapılan öğretimin etkililiği. (Yayımlanmış Yüksek Lisans Tezi) Gazi Üniversitesi Eğitim Bilimleri Enstitüsü, Ankara.

Aydın, O. ve Cavkaytar, A. (2018). Yazma güçlüğü görülen öğrencilerin el yazısı okunaklık düzeylerinin arttırılmasında ipucunun giderek artırılması uygulamasıyla sunulan öğretimin etkililiği. Sakarya Üniversitesi Eğitim Fakültesi Dergisi, 36, 1-23.

Bay, Yalçın. (2010). Ses temelli cümle yöntemiyle ilk okuma-yazma öğretiminin değerlendirilmesi. Kuramsal Eğitimbilim, 3 (1), 164-181.

Bender, W. N. (2007). Learning Disabilities: Characteristics, identification, and teaching strategies. (Sixth Edition.) Pearson Education.

Crouch, A. L. \& Jakubecy, J.J. (2007). Dysgraphia: How it affects a student's performance and what can be done about it. Teaching Exceptional Children Plus, 3(3). 22.04.2019 tarihinde https://files.eric.ed.gov/fulltext/EJ967123.pdf adresinden ulaşılmıştır.

Çakıroğlu, O. (2015). İlkokul Türkçe ders kitaplarındaki tetinlerin okunabilirlik düzeylerinin özel öğrenme güçlüğü olan öğrenciler açısından değerlendirilmesi. Ilköğretim Online, 14 (2), 671-681.

Demirci, N., Toptaş Demirci, P. (2016). Özel Özel öğrenme güçlüğü olan çocukların kaba ve ince motor becerilerinin değerlendirilmesi. İnönü Üniversitesi Beden Eğitimi ve Spor Bilimleri Dergisi, 3 (1), 7-57.

Erdem, M. (2010). Eğitilebilir zihinsel engelli öğrencilere okuma yazma öğretiminde kullanılan ses temelli cümle ve cümle çözümleme yöntemlerine ilişkin öğretmen görüşleri. (Yayımlanmış Yüksek Lisans Tezi) Gaziosmanpaşa Üniversitesi Sosyal Bilimler Enstitüsü. Tokat.

İlker, Ö. ve Melekoğlu, M.A. (2017). İlköğretim döneminde özel öğrenme güçlüğü olan öğrencilerin yazma becerilerine ilişkin çalışmaların incelenmesi. Ankara Üniversitesi Eğitim Bilimleri Fakültesi Özel Eğitim Dergisi, 18, 1-27.

Kaya, B. (2016). Yazma güçlüğü olan bir ilkokul 4. sınıf öğrencisine bitişik eğik yazı öğretimi. International Periodical fort he Lenguages,Literatüre and History of Turkish or Turkic, 11 (3), 1407-1434.

Kodan, H. (2016). Yazma güçlügü olan üçüncü sinıf öğrencisinin el yazısı okunaklılığının geliştirilmesi: Eylem araştırması. Türkiye Sosyal Araştırmalar Dergis, 2, 523-539. 
Kuşdemir, Y., Kurban, H. ve Bulut, P. (2018). Yazma güçlüğü yaşayan bir öğrenci ile ilgili eylem araştırması. Uluslararası Türkçe Edebiyat Kültür Ĕ̆itim Dergisi Sayı, 7 (2), 1190-1209.

Memiş, A., Harmankaya, T. (2012). İlköğretim okulu 1.sınıf öğrencilerinin bitişik eğik yazısı hataları ile görsel algı düzeylerinin incelenmesi. Dicle Üniversitesi Ziya Gökalp Ĕ̈itim Fakültesi Dergisi, 19, 136-150.

Milli Eğitim Bakanlığı, (2005). "İlköğretim Türkçe dersi öğretim programı ve kılavuzu” (1-5.sinıflar). Ankara: Milli Eğitim Bakanlığı.

Özçivit Asfuroğlu, B. ve Fidan, S.T. (2016). Özgül öğrenme güçlügü. Osmangazi Tip Dergisi, 38 (1), 49-54.

Sarı, H. (2003). Özel eğitime muhtaç öğrencilerin eğitimleriyle ilgili çă̆daş öneriler. Ankara: Pegem Yayıncilı.

Tok, Ş., Tok, T.N. ve Mazı, A. (2008). İlkokuma yazma öğretiminde çözümleme ve ses temelli cümle yöntemlerinin değerlendirilmesi. Kuram ve Uygulamada Ĕ̈itim Yönetimi, 53, 123-144.

Yıldırım, A., Şimşek, H. (2013). Sosyal bilimlerde nitel araştırma yöntemleri. Ankara: Seçkin Yayıncllk.

Yıldırım, K. (2007). Yazılı program ve uygulanan program kavramları açısindan ses temelli cümle yönteminin değerlendirilmesi. Milli Eğitim Dergisi, 175, 25-46.

Yıldız, M. (2013). Yazma güçlüğü (Disgrafi) olan bir ilkokul 2. sınıf öğrencisinin el yazısı okunaklılığının geliştirilmesi: Eylem araştırması. Uşak Üniversitesi Sosyal Bilimler Dergisi, 16, 281-310.

\section{Kaynakça Bilgisi / Citation Information}

Çıkılı, Y., Deniz, S. ve Kaya, H. B. (2019). Dik temel yazı çalışmalarının özel öğrenme güçlüğü olan öğrencinin yazım hatalarını düzeltmesine etkisi. OPUS-Uluslararası Toplum Araştırmaları Dergisi, 11(18), 501-529. DOI: 10.26466/opus.549544 